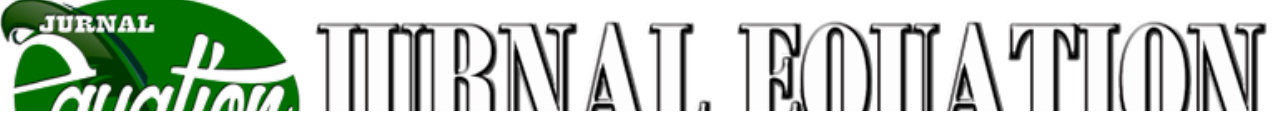 \\ Volume 2 Nomor 1, Maret 2019, ISSN 2599-3291 (Cetak), ISSN 2614-3933 (Online)
}

\section{Logika (Vlog Matematika): \\ Solusi dalam Menciptakan Generasi Cerdas dan Berbudaya}

\author{
Saprida Yani Harahap ${ }^{1)}$, Melvi Khairani²), Siti Masitoh ${ }^{3)}$ \\ Pendidikan Matematika Universitas Bengkulu
}

sapridayaniharahap@gmail.com

\begin{abstract}
ABSTRAK
Kendala yang paling sering ditemukan dalam pembelajaran matematika adalah materinya yang abstrak sehingga susah untuk dipahami pelajar padahal sebenarnya erat kaitannya dengan kehidupan sehari-hari. Mengaitkan matematika dengan masalah kehidupan sehari-hari dapat mempermudah pelajar dalam memahami matematika terutama jika disampaikan dengan objek yang sarat dengan latar belakang budaya pelajarnya. Matematika dihubungkan dengan budaya akan menghasilkan suatu pembelajaran yang menyenangkan dan mudah dipahami dikenal dengan "etnomatematika", perpaduan antara matematika dan budaya mengasilkan perubahan baru dalam matematika, selain itu etnomatematika dapat membuat pelajar mengetahui kebudayaan mereka lebih dalam sehingga kebudayaan akan tetap terlestarikan dan menumbuhkan rasa cinta akan budaya dan sejarah. Perubahan pola pikir matematika dari yang susah menjadi mudah dan menyenangkan tentu dapat meningkatkan kualitas pemahaman akan materi matematika itu sendiri. Maka kami menghadirkan solusi berupa vlog etnomatematika (LOGIKA) yakni media pembelajaran modern berupa video mengenai pembelajaran metematika dengan etnomatematika yang diselipkan budaya terutama budaya Bengkulu dan memanfaatkan gaya belajar audio dan visual pelajar sehingga mudah untuk dipahami baik siswa maupun mahasiswa.
\end{abstract}

Kata Kunci : Budaya, Etnomatematika, Matematika, Media, Vlog 


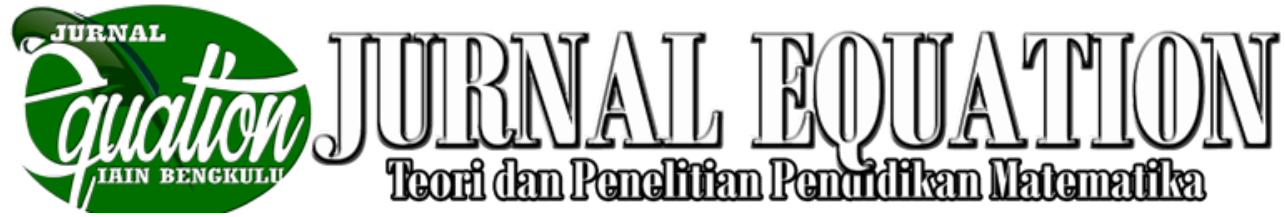

Volume 2 Nomor 1, Maret 2019, ISSN 2599-3291 (Cetak), ISSN 2614-3933 (Online)

\section{PENDAHULUAN}

Dalam kehidupan sehari-hari baik disadari atau tidak, setiap orang telah menerapkan konsep matematika dalam kegiatannya. Matematika yang selama ini terkesan susah dipahami, nyatanya memiliki peran yang sangat penting bagi kehidupan mulai dari hal sederhana sampai hal rumit sekalipun. Aktivitas matematika tersebut merupakan proses dari pengalaman nyata kehidupan sehari- hari ke dalam matematika atau sebaliknya, meliputi aktivitas berhitung, mengukur, mengelompokkan, merancang bangunan, membuat pola, menentukan lokasi, bermain dan sebagainya.. Hasil studi PISA dan TIMSS tahun 2015, menempatkan Indonesia pada peringkat dibawah rata-rata. Skor TIMSS pada bidang matematika memperoleh 397 , menempatkan Indonesia di nomor 45 dari 50 negara. Jika tidak ditanggapi secara serius hal ini dapat menjadi masalah serius bagi kemajuan pendidikan, teknologi dan berbagai aspek di Indonesia.

Salah satu alternative untuk mempernaiki kualitas pendidikan matematika di Indonesia adalah dengan melakukan pembelajaran yang menarik dan menyenangkan melaui pembelajaran matematika berbasis budaya. Pembelajaran berbasis budaya memberikan ruang kepada siswa untuk memberikan pemaksaan secara kontekstual berdasarkan pengalaman siswa sebagai bagian dari suatu masyarakat budaya. (Wahyuni, 2015). Etnomatematika merupakan sebagai suatu pendekatan yang mengaitkan antara matematika dengan budaya, pengaitan ini diharapkan mampu mampu meningkatkan kecintaan siswa terhadap budaya sehingga membuat siswa dapat mengetahui manfaat matematika dalam perspektif budaya (Kencanawati dan Irawan, 2017).

Dengan adanya penerapan etnomatematika dalam pembelajaran dalam membantu pelajar dalam memahami konsep matematika dan mengubah persepsi matematika yang tadinya susah menjadi lebih mudah karena terkait kehidupan sehari-hari. Selain itu etnomatematika yang berkaitan dengan budaya dapat memicu rasa ingin tau pelajar akan budaya sekitar sehingga para pelajar akan lebih tau mengenai budaya dan tradisi yang ada dilingkungan sekitar ditengah arus globalisasi yang secara perlahan mengikis budaya lokal dalam hati para pelajar.Oleh karena itu kami sebagai mahasiswa ingin merubah pola pikir para pelajar terkit matematika dan berperan dalam meningkatkan kualitas pendidikan matematika dengan menghadirkan inovasi 


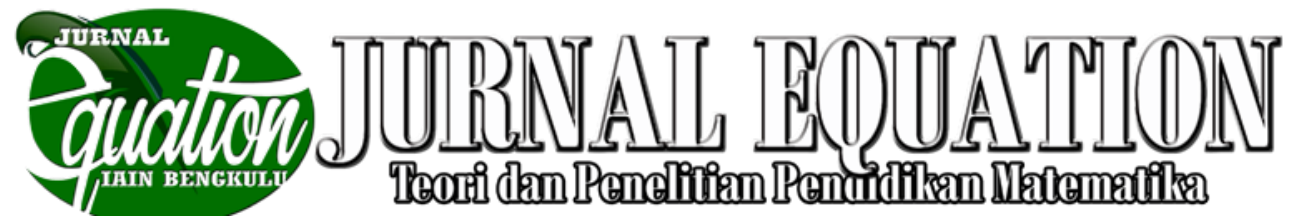

Volume 2 Nomor 1, Maret 2019, ISSN 2599-3291 (Cetak), ISSN 2614-3933 (Online)

pembelajaran matematika berupa Vlog Etnomatika (Logika). Vlog Etnomatika (Logika ) adalah solusi yang efektif dalam mengatasi permasalahan dalam pembelajaran matematika yakni dengan mengaitkan matematika dengan kehidupan sehari-hari, yang kemudian dipadukan dengan budaya lokal guna menciptakan generasi yang berbudaya dan cinta tanah air. Selain itu, maraknya penggunakan sosial media seperti youtube dapat menjadi sarana yang efektif dalam menyebarkan etnomatika kepada pelajar secara luas dan menyenangkan sehingga matematika tidak terkesan kaku dan menyulitkan.

Bertolak dari latar belakang, masalah yang dibahas dalam karya tulis ini yaitu: Bagaimana cara mengubah pola pikir pelajar mengenai pelajaran matematika yang sulit sehingga mampu meningkatkan kualitas pendidikan matematika di Indonesia terutama di Bengkulu?

\section{Definisi Matematika dan Matematika Sekolah}

Program pendidikan yang dapat mengembangkan kemampuan berpikir kritis, sistematis, logis, dan kreatif. Salah satu program pendidikan yang dapat mengembangkan kemampuan berpikir kritis, sistematis, logis, dan kreatif adalah matematika. (Wittgenstein, 1991). Matematika adalah logika mengenai bentuk, susunan, besaran, konsep-konsep yang saling berhubungan dengan yang lain yang jumlahnya banyak (Ruseffendi, 1990). Berdasarkan asal katanya yaitu mathematica, maka matematika berarti ilmu pengetahuan yang didapat dengan berpikir (Suherman, dkk., 2003: 15-16).

Matematika adalah suatu cara untuk menemukan jawaban terhadap masalah yang dihadapi manusia; suatu cara menggunakan informasi, menggunakan pengetahuan tentang betuk dan ukuran, menggunakan pengetahuan tentang menghitung, dan yang paling penting adalah memikirkan dalam diri manusia itu sendiri dalam melihat dan menggunakan hubunganhubungan. Secara tidak langsung dapat dikatakan bahwa matematika adalah suatu cara yang digunakan untuk menemukan jawaban terhadap masalah yang dihadapi manusia dengan mengembangkan kemampuan berpikir kritis, sistematis, logis, dan kreatif.

Dalam Permendikbud no. 59 Tahun 2004 tentang kurikulum 2013 SMA/MA disebutkan, ada beberapa karakteristik Matematika, antara lain : (1) objek yang dipelajari abstrak; (2) kebenarannya berdasarkan logika; (3) pembelajarannya 


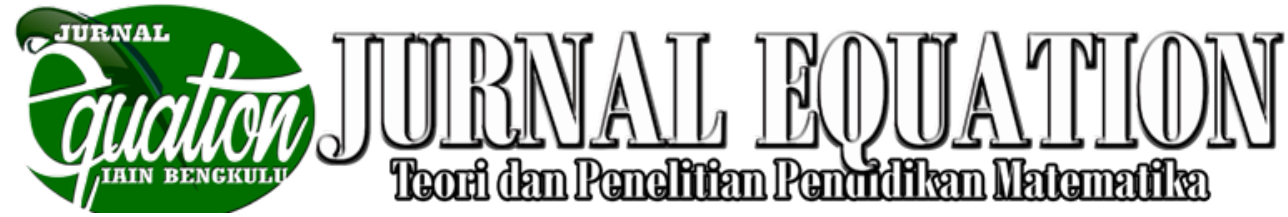

Volume 2 Nomor 1, Maret 2019, ISSN 2599-3291 (Cetak), ISSN 2614-3933 (Online)

secara bertingkat dan kontinu; (4) ada keterkaitan antara materi yang satu dengan yang lainnya; (5) menggunakan bahasa simbol; (6) diaplikasikan di bidang ilmu lain. Matematika mulai diajarkan kepada siswa sejak jenjang sekolah dasar, sehingga siswa mengenal matematika secara bertahap dimulai dari yang paling dasar. Namun ketika memasuki jenjang sekolah menegah pertama dan menengah atas banyak siswa yang mulai mengalami masalah ketika memahami matematika.

Matematika yang diajarkan disetiap jenjang sekolah dinamakan matematika sekolah (Sriyanto, 2017).

\section{Budaya}

Budaya atau kebudayaan berasal dari bahasa Sansekerta yaitu buddhayah, yang merupakan bentuk jamak dari buddhi (budi atau akal) diartikan sebagai hal- hal yang berkaitan dengan budi dan akal manusia. Dalam bahasa Inggris, kebudayaan disebut culture, yang berasal dari kata Latin Colere, yaitu mengolah atau mengerjakan. Bisa diartikan juga sebagai mengolah tanah atau bertani. Kata culture juga kadang diterjemahkan sebagai "kultur" dalam bahasa Indonesia.
Menurut Matthew (1869), Budaya adalah suatu cara hidup yang berkembang dan dimiliki bersama oleh sebuah kelompok orang dan diwariskan dari generasi ke generasi. Budaya terbentuk dari banyak unsur yang rumit, termasuk sistem agama dan politik, adat istiadat, bahasa, perkakas, pakaian, bangunan, dan karya seni. bahasa, sebagaimana juga budaya, merupakan bagian tak terpisahkan dari diri manusia sehingga banyak orang cenderung menganggapnya diwariskan secara genetis. Ketika seseorang berusaha berkomunikasi dengan orang-orang yang berbada budaya dan menyesuaikan perbedaan perbedaannya, membuktikan bahwa budaya itu dipelajari.

\section{Etnomatematika}

Etnomatematika di Indonesia bukanlah sesuatu ilmu pengetahuan yang baru, melainkan sudah dikenal sejak diperkenalkan ilmu matematika itu sendiri. Hanya saja disiplin ilmu ini disadari setelah beberapa ilmuwan memperkenalkannya. Istilah etnomatematika berasal dari kata ethnomathematics, yang diperkenalkan oleh D'Ambrosio seorang matematikawan Brasil pada tahun 1977. Terbentuk dari kata ethno, mathema, dan tics. Awalan ethno mengacu 


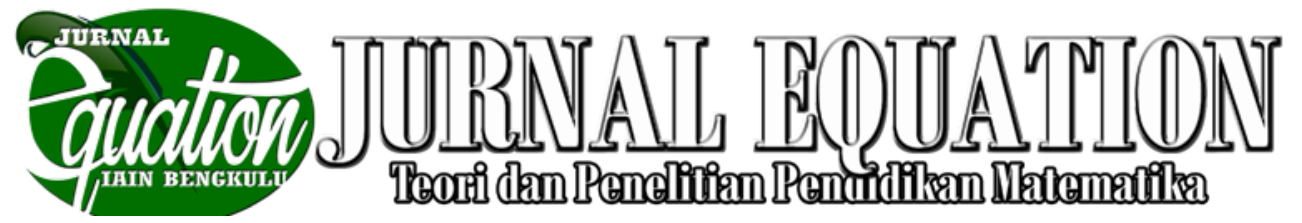

Volume 2 Nomor 1, Maret 2019, ISSN 2599-3291 (Cetak), ISSN 2614-3933 (Online)

pada kelompok kebudayaan yang dapat dikenali, seperti perkumpulan suku di suatu negara dan kelas-kelas profesi di masyarakat, termasuk pula bahasa dan kebiasaan mereka sehari-hari. Kemudian, mathema disini berarti menjelaskan, mengerti, dan mengelola hal - hal nyata secara spesifik dengan menghitung, mengukur,

mengklasifikasi, mengurutkan, dan memodelkan suatu pola yang muncul pada suatu lingkungan. Akhiran tics mengandung arti seni dalam teknik.

Secara istilah etnomatematika diartikan sebagai matematika yang dipraktikkan di antara kelompok budaya diidentifikasi seperti masyarakat nasional suku, kelompok buruh, anak-anak dari kelompok usia tertentu dan kelas professional (D'Ambrosio, 1985: 44-48). Lebih luas lagi, jika ditinjau dari sudut pandang riset, maka etnomatematika didefinisikan sebagai antropologi budaya (cultural antrophology of mathematics) dari matematika dan pendidikan matematika (D'Ambrosio, 2006: 1). Berdasarkan penjelasan tersebut dapat disimpulkan bahwa etnomatematika merupakan suatu cara atau kegiatan yang digunakan untuk mengembangkan matematika pada suatu kelompok tertentu dalam lingkup sosio - kultur - budaya

\section{Peran Etnomatematika dalam Pembelajaran Matematika}

Pembelajaran matematika membutuhkan suatu pendekatan agar dalam pelaksanaanya memberikan keefektifan. Sebagaimana dari salah satu tujuan pembelajaran itu sendiri bahwa pembelajaran dilakukan agar peserta didik dapat mampu menguasai konten atau materi yang diajarkan dan menerangkannya dalam memecahkan masalah. Untuk mencapai tujuan pembelaaran ini mestinya guru lebih memahami faktor apa saja yang berpengaruh dalam lingkungan siswa terhadap pembelajaran.

Salah satu faktor yang berpengaruh dalam pembelajaran adalah budaya yang ada di dalam lingkungan masyarakat yang siswa tempati. Budaya sangat menentukan bagaimana cara pandang siswa dalam menyikapi sesuatu. Termasuk dalam memahami suatu matematika. Ketika suatu materi begitu jauh dari skema budaya yang mereka miliki tentunya materi tersebut sulit untuk difahami. Untuk itu diperlukan suatu pendekatan dalam pembelajaran matematika yang mampu menghubungkan antara matematika dengan budaya mereka. 


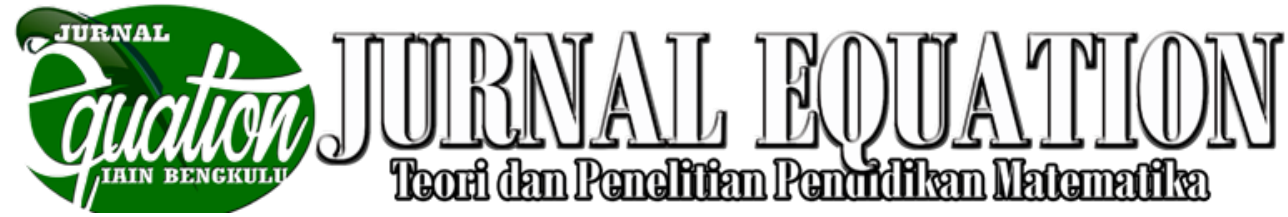

Volume 2 Nomor 1, Maret 2019, ISSN 2599-3291 (Cetak), ISSN 2614-3933 (Online)

(Wahyuni,A., dkk., 2013: 116).

Etnomatematika merupakan jembatan matematika dengan budaya, sebagaimana telah dijelaskan sebelumnya bahwa etnomatematika mengakui adanya cara-cara berbeda dalam melakukan matematika dalam aktivitas masyarakat. Dengan menerapakan etnomatematika sebagai suatu pendekatan pembelajaran akan sangat memungkinkan suatu materi yang dipelajari terkait dengan budaya mereka sehingga pemahaman suatu materi oleh siswa menjadi lebih mudah karena materi tersebut terkait langsung dengan budaya mereka yang merupakan aktivitas mereka sehari- hari dalam bermasyarakat. (Wahyuni, A., dkk., 2013: 116).

Salah satu bentuk penerapan etnomatematika dalam pembelajaran matematika adalah penggunaan lidi untuk konsep operasi perkalian pada bilangan bulat. Budaya yang terdapat dalam pembelajaran ini adalah penggunaan lidi merupakan bagian dari alat pembersih yang biasa digunakan untuk menyapu halaman atau tempat yang kotor Dengan adanya bentuk pembelajaran ini siswa lebih mudah dalam menerima dan memahami materi yang disampaikan oleh guru dan hasil belajar siswa pun mengalami perbaikan.

\section{Definsi Video Blog (Vlog)}

Vlog adalah satu video yang berisi mengenai opini, cerita atau kegiatan harian yang biasanya dibuat tertulis pada blog (Eribka, dkk., 2017). Vlog di unggah pada laman youtube untuk memudahkan diakses oleh siapa saja. Pada saat di vlog sudah menjadi gaya hidup baru diantara remaja. Menurut Henri S. selaku staff dari KEMENKOMINFO dalam Annisa bahwa berdasarkan data Komisi penyiaran Indonesia (KPI) pada tahun 2016, jumlah penonton televisi menurun drastis. Disisi lain terdapat peningkatan jumlah penonton youtube menjadi rata- rata 200 juta kali per satu video unggahan.

Vlog menjadi salah satu konten yang paling dominan di youtube pada saat ini. Video yang di kategorikan dengan vlog adalah video monolog. Para Vlogger dapat membicarakan berbagai pandangan dirinya terkait politik, social-budaya, hingga beragam hal dalam kehidupan sehari-hari (Burgess \& Green, 2009 dalam Mahameruaji, dkk). Vlogger mencampaikan pandangannya dengan bahasa yang mudah dipahami oleh berbagai kalangan masyarakat dan disajikan dengan semenarik mungkin.

\section{Vlog sebagai Media Belajar Matematika}




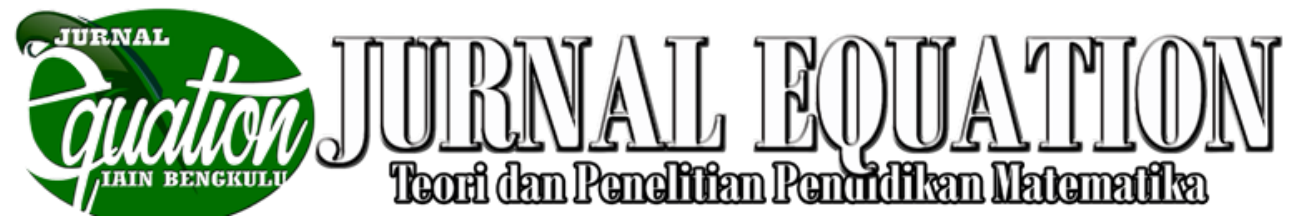

Volume 2 Nomor 1, Maret 2019, ISSN 2599-3291 (Cetak), ISSN 2614-3933 (Online)

Tuntutan global yang membawa dunia pendidikan untuk turut berkembang menyesuaikan terhadap perkembangan teknologi untuk meningkatkan kualitas pendidikan. Hal ini menyebabkan para pendidik dituntut untuk melakukan berbagai inovasi dan kreativitas agar proses pembelajaran sejalan dengan perkembangan teknologi saat ini (Priana, 2017). Metode pembelajaranpun juga harus disesuaikan dengan perkembangan teknologi pada saat ini. Metode ceramah didepan kelas sebaiknya sudah harus dikembangkan menjadi E-Learning. Menurut Adawi, konsep pembelajaran ini menggunakan komputer dan jaringan dengan memanfaatkan teknologi web dan internet.

Menurut Priana (2017) Kreatifitas pendidik maupun peserta didik baik dalam penyampaian materi maupun presentasi dengan menggunakan vlog membuat penyajian pembelajaran menjadi interaktif sehingga terdapat daya tarik tersendiri bagi para siswa dibandingkan dengan metode konfensional yang selama ini diterapkan. Dengan memanfaatkan teknologi pada saat ini, melalui vlog sebagai media pembelajaran matematika diharapkan minat belajar matematika meningkat dan menjadikan matematika lebih mudah dipahami oleh siswa.

\section{METODE PENULISAN}

Metode penulisan merupakan pendekatan yang digunakan untuk mengumpulkan data, mengolah data, menganalisis data dan kerangka berfikir dengan teknik tertentu.

\section{Teknik Pengumpulan data}

Sesuai dengan sumber data maka dalam pengumpulan data penulis menggunakan beberapa metode sebagai berikut:

\section{Studi Kepustakaan}

Suau metode pengumpulan data yang dilakukan dengan cara menggunakan dan mempelajari buku, jurnal, internet atau media lainnya yang berhubungan dengan karya tulis ini sebagai penunjang dalam mengambil teori dasar.

\section{Penelitian lapagan}

Suatu metode pengumpulan data yang dilakukan dengan meninjau dan mengamati langsung, hal ini meliputi interview ( wawancara) terhadap pihak-pihak yang terlibat dengan karya tulis ini.

\section{Rancangan Penulisan}

Agar tulisan yang dibuat efisien dan efektif, disusunlah kerangka tulisan berdasarkan topic tulisan yang diangkat. Berdasarkan 


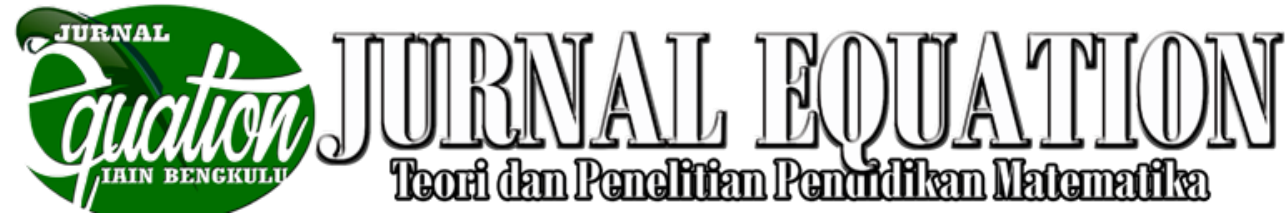

Volume 2 Nomor 1, Maret 2019, ISSN 2599-3291 (Cetak), ISSN 2614-3933 (Online)

kerangka tulisan itulah kemudian data dikumpulkan, disusun, diolah lalu ditafsirkan. Hasil tafsiran kemudian dianalisis sehingga dihasilkan sebuah kesimpulan. Hasil analisis dan sintesis ini berupa gagasan baru untuk memecahkan permasalahan yang ditemukan dalam literature.

\section{Teknik penarikan kesimpulan}

Kesimpulan dibuat menggunakan pola pikir induktif, yakni menarik kesimpulan sebagian dari hasil penelitian serta sumber referensi data. Sedangkan saran dibuat berdasarkan hasil kesimpulan.

\section{HASIL DAN PEMBAHASAN}

\section{Gambaran Umum Pembelajaran Matematika Saat Ini}

Matematika selama ini termasuk ilmu pengetahuan yang dianggap berat, sehingga tak jarang dianggap tidak menarik. kebanyakan dari pelajar menganggap bahwa matematika itu sulit untuk diaplikasikan dalam kehidupan sehari-hari dan hanya sebatas teori saja, padahal matematika itu sangat banyak kegunaannya dalam kehidupan sehari-hari. Tak jarang ditemui pembelajaran matematika di sekolah terkesan monoton yakni hanya sebatas pengenalan rumus lalu soal latihan, ditambah pembawaan guru yang tidak ramah pada siswa atau mahasiswanya membuat pelajaran matematika kerap di cap mengerikan.

Sebuah pendekatan yang dapat digunakan untuk menjelaskan realitas hubungan antara budaya lingkungan dan matematika saat mengajar adalah etnomatematika. Jika kita tengok negara-negara lain, keberhasilannegara Jepang dan Tionghoa dalam pembelajaran matematika karena mereka menggunakan Etnomatematika dalam pembelajaran matematikanya.(Uloko dan Imoko, 2007).

Etnomatematika adalah matematika yang diterapkan oleh kelompok budaya tertentu, kelompok buruh/petani, anak-anak dari masyarakat kelas tertentu, kelas-kelas profesional, dan lain sebagainya (Gerdes, 1994). Dari definisi seperti ini, maka etnomatematika memiliki pengertian yang lebih luas dari hanya sekedar etno (etnis) atau suku. Jika ditinjau dari sudut pandang riset maka etnomatematika didefinisikan sebagai antropologi budaya (cultural anropology of mathematics) dari matematika dan pendidikan matematika. Mengapa etnomatematika menjadi disiplin ilmu dan menjadi perhatian luas akhir-akhir ini. Salah satu alasan yang bisa dikemukakan adalah karena pengajaran matematika di sekolah memang terlalu 


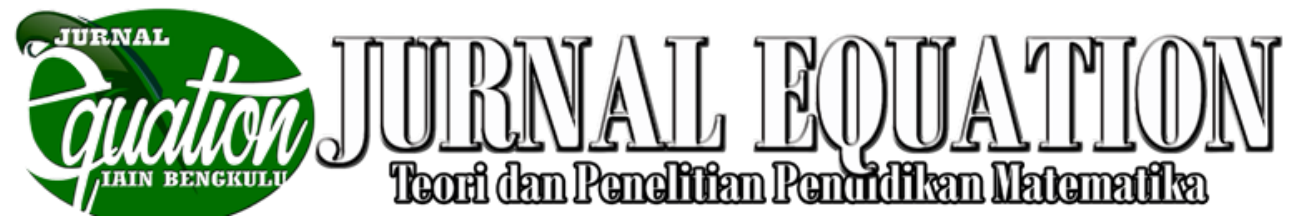

Volume 2 Nomor 1, Maret 2019, ISSN 2599-3291 (Cetak), ISSN 2614-3933 (Online)

bersifat formal. Hiebert \& Capenter (1992) mengingatkan kepada semua pihak bahwa pengajaran matematika di sekolah dan matematika yang ditemukan anak dalam kehidupan sehari-hari sangat berbeda. Oleh sebabitu pembelajaran matematika sangat perlu memberikan muatan/menjembatani antara

matematika dalam dunia sehari-hari yang berbasis pada budaya lokal dengan matematika sekolah.

Gagasan etnomatematika akan dapat memperkaya pengetauan matematika yang telah ada. Oleh sebab itu, jika perkembangan etnomatematika telah banyak dikaji maka bukan tidak mungkin matematika diajarkan secara bersahaja dengan mengambil budaya setempat. Matematika merupakan suatu bentuk budaya. Matematika sebagai bentuk budaya, sesungguhnya telah terintegrasi pada seluruh aspek kehidupan masyarakat dimanapun berada, (Bioshop, 1994). Pada hakekatnya matematika merupakan teknologi simbolis yang tumbuh pada keterampilan atau aktivitas lingkungan yang bersifat budaya. Dengan demikian matematika seseorang dipengaruhi oleh latar budayanya, karena yang mereka lakukan berdasarkan apa yang mereka lihat dan rasakan. Budaya akan mempengaruhi perilaku individu dan mempunyai peran yang besar pada perkembangan pemahaman individual, termasuk pembelajaran matematika (Bishop, 1991). Pendidikan matematika sesungguhnya telah menyatu dengan kehidupan masyarakat itu sendiri. Kenyataan tersebut bertentangan dengan aliran "konvensional" yang memandang matematika sebagai ilmu pengetahuan yang "bebas budaya" dan bebas nilai. Para pakar etnomatematika berpendapat bahwa pada dasarnya perkembangan matematika sampai kapanpun tidak terlepas dari budaya dan nilai yang telah ada pada masyarakat.

\section{Solusi Yang Di Tawarkan}

Selama ini pembelajaran matematika di sekolah masih sangat monoton yakni hanya menjelaskan dengan gambar di papan tulis atau meminta siswa maupun mahasiswa membayangkannya sendiri, hal ini tentu mempersulit dalam memahami matematika. Namun, ada juga beberapa guru yang kreatif yakni menghadirkan media pembelajaran non tik ke kelas-kelas untuk membuat siswa ataupun mahasiswa memahami materi yang diajarkan, namun hal ini tetap kurang efektif karena siswa hanya mampu menyerap sekitar $40 \%$ saja dari pembelajaran di kelas. 


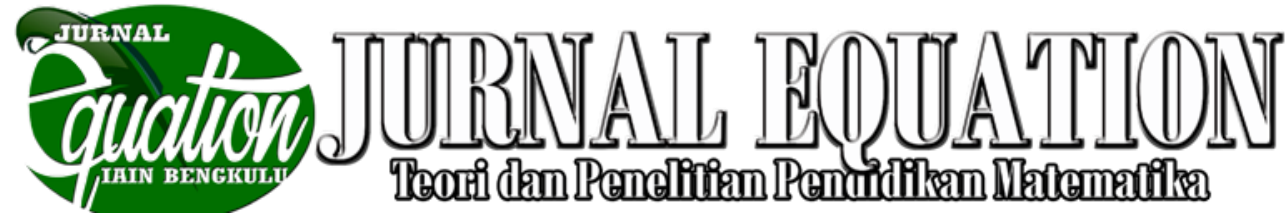

Volume 2 Nomor 1, Maret 2019, ISSN 2599-3291 (Cetak), ISSN 2614-3933 (Online)

Oleh karena itu kami menciptakan media pembelajaran berupa video dimana video ini dapat merangsang audio dan visual peserta didik serta dapat diulang hingga paham. Video pembelajaran yang kami hadirkan ini memuat pembelajaran kontekstual pada pelajar dan berkaitan dengan budaya terutama budaya Bengkulu dalam hal ini disebut etnomatematika.

\section{Langkah-Langkah Implementasi Gagasan}

Langkah strategis perlu direncanakan dengan matang agar konsep ini dapat terealisasi dengan baik . Melihat pentingnya inovasi media belajar yang menyenanngkan dan mudah dipahami maka dibutuhkan pergerakan yang nyata dari agen perubahan yakni kami sebagai mahasiswa. Hal ini dapat dicapat melalui gagasan kami yakni menciptakan media pembelajaran LOGIKA (Vlog Etnomatematika) yang merupakan video pembelajaran yang menarik berbasis kebudayaan untuk mempermudah pelajar dalam memahami materi matematika dan merubah pola pikir tentang matematika yang awalnya susah menjadi mudah. Untuk itu, dalam mencapai tujuan tersebut harus ada langkah strategis dalam hal ini kami memanfaatkan sosial media seperti yakni
You Tube, karena mengekspos video kami lewat You Tube dapat mengenalkan pembelajaran etnomatika dengan budaya secara luas dan membuat citra matematika yang mudah semakin cepat.

Dalam pembuatan video ada beberapa langkah yang kami lakukan yakni sebagai berikut:

1. Mendatangi tempat bersejarah yang merupakan cagar budaya yang ada di Bengkulu

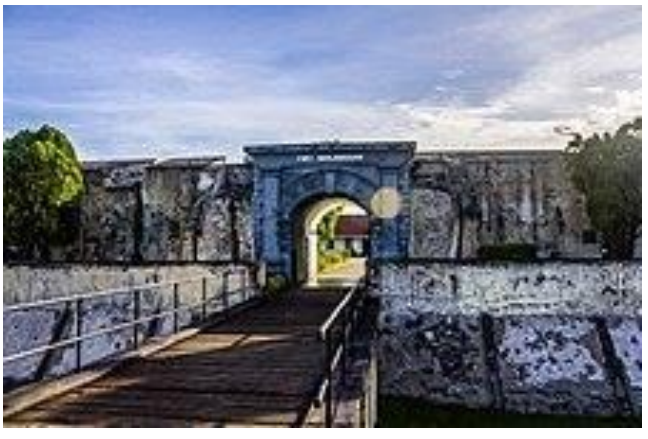

Gambar 1. Tempat Bersejarah di Bengkulu

Misalnya dalam menjelaskan materi sudut deviasi dan elevasi kami memilih objek pengukuran tinggi gedung Benteng Fort Malborough dan melakukan pengambilan video disana dengan langsung mengukur tinggi gedungnya di Benteng tersebut, selain itu dalam video akan dijelaskan mengenai asal usul Benteng Fort Malborough sehingga yang menonton video kami nanti tidak hanya mendapat wawasan seputar matematika namun juga tentang sejarah dan budaya 


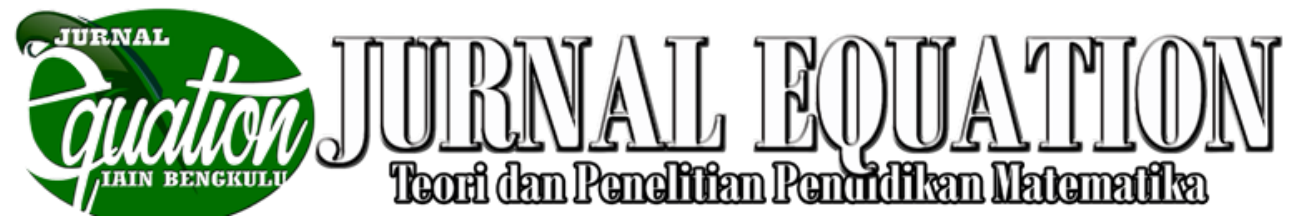

Volume 2 Nomor 1, Maret 2019, ISSN 2599-3291 (Cetak), ISSN 2614-3933 (Online)

guna menciptakan rasa cinta tanah air.

2. Melakukan Pengukuran

Kami melakukan pengukuran ketinggian benteng tersebut dengan menggunakan alat yaitu klinometer atau melakukan dan menjelaskan operasi hitung matematika terkait konsep materi yang sedang dibuat dengan menjelaskan setiap langkah dengan detail menggunakan bahasa Bengkulu karena pembelajaran etnomatematika yang dituju adalah pelajar dari daerah Bengkulu.

\section{Evaluasi dari Hasil Pengukuran}

Kami akan melakuka review mengenai hasil pengukuran dan menjelaskan kegunaan konsep yang diajarkan pada soal-soal yang lainnya

4. Pengunggahan Video ke Media Sosial

Video yang dibuat akan diunggah di situs You Tube kami dan akan dipromosikan melalui media sosial lainnya seperi Instagram dan Facebook guna memviralkan media pembelajaran ini sehinggadilihat oleh banyak orang dan mampu mencapai tujuan pembuatannya.

\section{Hasil Yang Diharapkan}

Dari kegiatan yang telah kami lakukan sangatlah banyak yang kami harapkan melalui vlog etnomatematika ini, penerapan pembelajaran matematika yang di hubungkan dengan kebudayaan akan menimbulkan kemanfaatan dan efek yang besar dalam pembelajaran metematika, maka harapannya adalah: Merubah pola pikir para pelajar mengenai pembelajaran matematika, yang awalnya membuat mereka sulit dipahami menjadi sesuatau yang menarik untuk mempelajarinya; Program ini dapat berkembang lebih baik dan menjadi solusi dalam menciptaka generasi-generasi yang cerdas tapi tidak melupakan budaya; dan Menjadi tolak ukur bagi para guru untuk mengajarkan kepada siswanya sehingga tidak hanya monoton pada teori saja tanpa ada pengaplikasian dalam pembelajarannya. Kegiatan ini diharapkan mampu menginovasi suatu pembelajaran matematika menjadi sesuatu yang memiliki banyak manfaat dan kegunaannya dalam kehidupan sehari-hari, sehingga mereka bisa mengaplikasikan apa yang mereka pelajari.

\section{Pihak Yang Terlibat}

Guru

Guru sebagai seseorang yang sangat berpengaruh dalam pembelajaran dan seseorang yang mmberikan ilmu nya kepada muridnya memiliki peran yang sangat penting dalam keseksesan suatu pe 


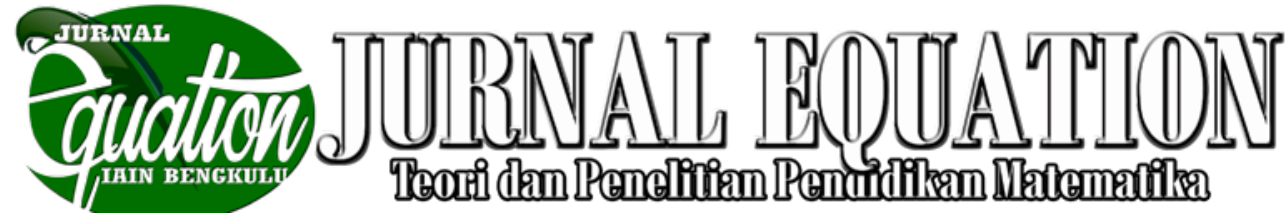

Volume 2 Nomor 1, Maret 2019, ISSN 2599-3291 (Cetak), ISSN 2614-3933 (Online)

mbelajaran, gaya pengajaran yang menarik dapat lebih mudah untuk diterima dan dipahami oleh muridnya, matematika senagai suatu pelajaran yang sangat di hindari akan menjadi suatu tantangan bagi guru untuk merubahnuya menjadi sesuatu yang sangat menarik dan banyak di minati muridnya, maka dengan pengajaran matematika yang dikolaborasikan dengan kebnudayaan akan menjadi nilai daya tarik bagi guru sehingga membuat murid mudahuntuk memahami pelajaran.

Pelajar

Pelajar adalah individu yang ikut dalam kegiatan belajar untuk mendapatkan ilmu pengetahuan. Pelajar merupakan aset yang sangat penting bagi suatu negara. Karena generasi penerus banga yang diharapkan adalah pelajar yang nantinya dapat menjadi individu yang dapat memajukan agama, bangsa dan negara. Selain itu, pelajaryang diharapkan adalah generasi yang nantinya dapat membuat pergaulan sosial juga semakin baik. Juga yang dapat menjaga kelestarian budaya.kata pelajar sendiri mencakup siswa dan mahasiswa Sehingga sebagai objek dalam pendidikan pelajar diharapkan dapat menjadi seseorang yang dapat merubah sesuatu yang sulit menjadi mudah untuk di pelajari.

\section{PENUTUP}

Kesimpulan

Berdasarkan penjelasan sebelumnya kita dapat mengetahui bahwa perlu dilakukan inovasi pembelajaran matematika yang menyenangkan dan kontekstual bagi para pelajar. Dalam hal ini etnomatematika adalah solusi yang paling efektif untuk menghadirkan pembelajaran matematika secara kontekstual kepada pelajarnya. Etnomatematika erat kaitannya dengan budaya para pelajar yang menjadi sasaran pembelajran sehingga konsep matematika akan lebih cepat diterima oleh siswa dan mampu menghadirkan rasa cinta akan budaya pada pelajar. Budaya dapat disisipkan sebagai objek yang diukur, diteliti atau dihitung oleh pelajar sehingga pembelajaran yang awalnya terksesan abstrak akan menjadi nyata. Selain itu pemanfaatan media sosial seperti Youtube sangat efektif mengingat pelajar zaman sekarang lebih suka menonotn daripada membaca, dan cara ini akan terkesan lebih modern dan mampu merangsang audio dan visual dari pelajar dengan tampilan yang menarik dan mudah dipahami.

\section{Saran}

Penulis mengharapkan inovasi media pembelajaran ini dapat menjadi inspirasi 


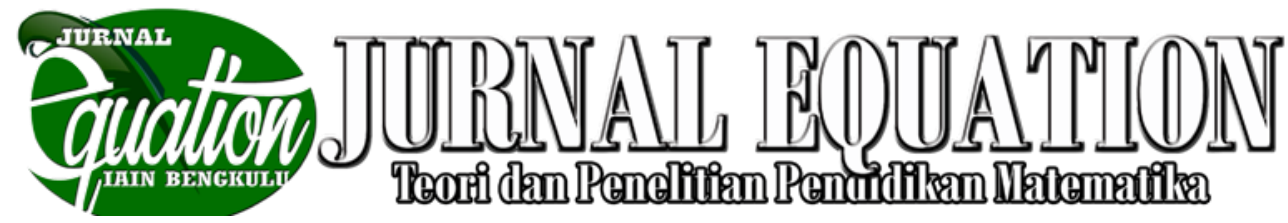

Volume 2 Nomor 1, Maret 2019, ISSN 2599-3291 (Cetak), ISSN 2614-3933 (Online)

untuk seluruh pembaca, baik mahasiswa, guru, dan masyarakat umum lainnya untuk bersama-sama menuangkan idenya demi terciptanya perbaikan kualitas pelajaran matematika di Indonesia. Serta berperan aktif dalam menjadi agen perubahan bagi Indonesia baik itu mencerdaskan anak bangsa juga menjadikan menanamkan rasa akan cinta budaya pada generasi kedepan. Kritik dan saran sangat diharapkan oleh penulis untuk kesempurnaan karya tulis ilmiah ini.

\section{DAFTAR PUSTAKA}

Arnold, Matthew. 1869. Culture and

Anarchy. New York: Macmillan.

Third edition, 1882, available online.

Retrieved: 2006-06-28.

Bishop,J.A.(1991).The Simbolic

Technology Calet Mathematics its

Role in Education.Bullatin De La

Societe Mathematique, De

Belgique, T,XLIII

Bishop,J.A.(1991).The Simbolic Technology

Calet Mathematics its Role in

Education.Bullatin De La Societe

Mathematique, De Belgique, T,XLIII

Bishop,J.A.(1994b). Cultural

Conplicts in the

Mathematics Education of
Indigenous people. Clyton,

Viktoria: Monash

University.

Burgess, J., \& Green, J. (2009b). The entrepreneurial Vlogger: Participatory culture beyond the professionalamateur divide. London, UK: Wallflower Press.

David, Eribka Ruthellia , Mariam Sondakh, Stefi Harilama. 2017. Pengaruh Konten Vlog dalam Youtube terhadap Pembentukan Sikap Mahasiswa IImu Komunikasi Fakultas IImu Sosial dan Politik Universitas Sam Ratulangi. Jurnal Acta Diurna Vol.VI, No. 1

D'Ambrosio, U., Ethnomathematics And Its Place In The History And Pedagogy Of Mathematics. For learning of Mathematics, 5 (1), 1985.

Gerdes,P.(1994). Reflection

on Ethnomatematics.

For the Learning of

Mathematiccs, 14(2), 19-21.

Grouws(Ed),Handbook of research on mathematics reaching andlearning.New York:Macmillan. Hiebert,J.\&Carpenter, T.P.(1992). Learning with understading. 


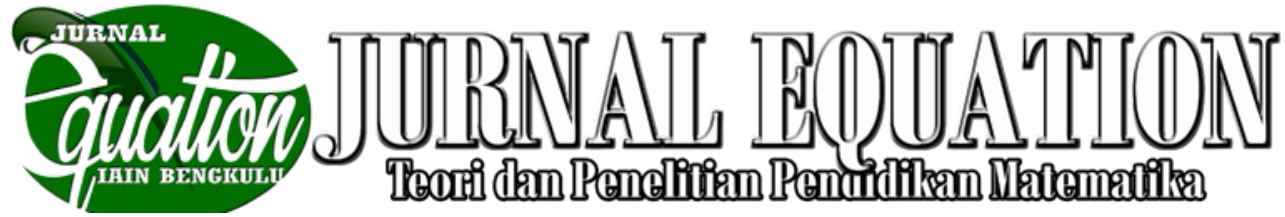

Volume 2 Nomor 1, Maret 2019, ISSN 2599-3291 (Cetak), ISSN 2614-3933 (Online)

Dalam D.G. Kencanawaty, G dan Irawan, A. 2017.

Penerapan Etnomatematika dalam

Pembelajaran Matematika di Sekolah

Berbasis Budaya. Ekuivalen, 27 (2), 169-179.

Priana, Ronny Yudhi Septa. 2017.

Pemanfaatan Vlog sebagai media pembelajaran teritegrasi tekhnologi informasi. Jurnal Prosiding Seminar Nasional Pendidikan FKIP UNTIRTA 2017.

Sriyanto,

H. J. 2017. Mengobarkan Api

Suherman, Erman dkk. 2003. Strategi

Pembelajaran Matematika

Kontemporer.

Bandung: PT Remaja Rosdakarya.

Uloko ES, Imoko BI (2007). Pengaruh

ethnomathematics mengajar

pendekatan dan jenis kelamin

terhadap prestasi siswa dalam

Lokus. J. Natl. Assoc. Sci. Humanit.

Educ. Res. 5 (1): 31-36

Wahyuni, Astri, Wedaring, Ayu Aji, dan Sani, Budiman, Peran Etnomatematika dalam Membangun Krakter Bangsa, Makalah Seminar Nasional Matematika dan Pendidikan Matematika, Prosiding, Jurusan Pendidikan Matematika FMIPA UNY, Yogyakarta: UNY, 2013

Wahyuni, I. 2015. Eksplorasi Etnomatematika Masyarakat Sidoarjo. Fenomena (Jurnal Penelitian Islam Indonesia), 15 (2), 225-238.

Wigati, Sri. 2014. Permendikbud No. 59 tahun 2014 tentang Kerangka Dasar Dan Struktur Kurikulum 2013 SMA/MA. Kementerian

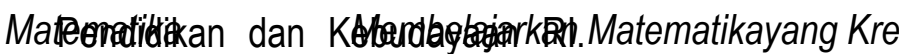
Jakarta. Fenomena (Jurnal Penelitian Islam Indonesia), 15 (2), 225-238. 